OECD Economics Department Working Papers No. 106

\title{
Energy Prices, Taxes and Carbon Dioxide \\ Emissions
}

\author{
Peter Hoeller, \\ Markku Wallin
}

https://dx.doi.org/10.1787/356365310851 


\title{
OCBDE \\ 盘艋 \\ OESD
}

ECONOMICS AND STATISTICS DEPARTMENT WORKING PAPERS

$N^{\circ} 106$

\section{ENERGY PRICES, TAXES AND CARBON DIOXIDE EMISSIONS}

\author{
by \\ Peter Hoeller and Markku Wallin \\ Public Economics Division
}

ORGANISATION FOR ECONOMIC CO-OPERATION AND DEVELOPMENT

Paris 1991 
GENERAL DISTRIBUTION

OCDE/GD ( 91$) 154$

\title{
ECONOMICS AND STATISTICS DEPARTMENT \\ WORKING PAPERS
}

NO. 106

ENERGY PRICES, TAXES AND

CARBON DIOXIDE EMISSIONS

\author{
by \\ Peter Hoeller and Markku Wallin \\ Public Economics Division
}

ORGANISATION FOR ECONOMIC CO-OPERATION AND DEVELOPMENT

Paris 1991

36027

FOR TECHNICAL REASONS, THIS DOCUMANT IS NOT AVAILABLE ON OLIS 
The authors would like to acknowledge the comments and suggestions of Andrew Dean, Jorgen Elmeskov, Constantino Lluch, John Martin and several colleagues in the Environment Directorate and the International Energy Agency. The authors are also indebted to Annick Lotrous and Sheena Bohan for their assistance. 


\title{
ECONOMICS AND STATISTICS DEPARTMENT
}

\section{WORKING PAPERS}

\begin{abstract}
This series of Working Papers is designed to make available, to a wider readership, selected studies which the Department has prepared for use within OECD. Authorship is generally collective, but main individual authors are named. The Papers are generally available in their original language, English or French, with a summary in the other.

Comment on the Papers is invited, and may be sent to OECD, Department of Economics and Statistics, 2 rue André Pascal, 75775 Paris Cedex 16, France. Additional copies of the Papers, on a limited basis, can be forwarded on request.
\end{abstract}

ORGANISATION FOR ECONOMIC CO-OPERATION AND DEVELOPPEMENT

Copyright OECD 1991 
Taxes levied on the carbon content of fuels (carbon taxes) are being considered in many OECD countries as a possible policy instrument to reduce carbon dioxide emissions. This paper first reviews the policy response in Member countries to the threat of global warming. It then discusses the link between carbon emission intensities and current energy prices, touching also on the relative price effects of current energy policies and the implicit carbon taxes reflected in present energy taxation for different fuels. Finally, the likely size of carbon taxes and associated tax revenue is illustrated by simulations of OECD's GREEN model for equiproportionate emission cuts and a global permit trading system.

Dans la plupart des pays de 1'OCDE on-considère les taxes perçues sur les combustibles en fonction de leur teneur en carbone (les taxes sur le carbone) comme un des moyens de réduire les émissions de dioxyde de carbone. Ce document passe en revue les réactions de politique économique des pays Membres face à la menace d'un réchauffement planétaire. Il étudie ensuite le lien entre les prix courants de l'énergie et l'intensité des émissions de carbone ainsi que les effets des politiques énergétiques sur les prix relatifs. Les effets de prix relatifs sont mis en évidence en calculant des taxes implicites sur le carbone qui reflètent le système actuel de taxation de l'énergie pour différents combustibles, Enfin le montant probable des taxes sur le carbone et des taxes sur le revenu qui y sont associées est illustré par des simulations du modèle GREEN de 1'OCDE concernant des réductions équiproportionnelles d'émissions et un système global d'échanges de droits d'émissions. 
TABLE OF CONTENTS

\section{Page}

I. INTRODUCTION AND SUMMARY

II. GLOBAL WARMING AND THE POLICY RESPONSE

III. ENERGY PRICES, TAXES AND EMISSION INTENSITIES

IV. ENERGY PRICE EFFECTS OF A CARBON TAX

v. THE REVENUE POTENTIAL OF A CARBON TAX

i) Equiproportionate cuts in emissions

ii) Setting a price per ton of emission globally

\section{TABLES}

1. $\mathrm{CO}_{2}$ emissions in OECD countries

2. Status of commitments to reducing greenhouse gas emissions

3. Carbon content and carbon emission coefficients

4. Implicit carbon taxes in $\mathbf{1 9 8 8}$

5. The mechanical effect of a $\$ 100$ tax per ton of carbon on energy prices

6. Fuel price implications of the Swedish tax reform

7. Tax revenue of a $\$ 100$ tax per ton of carbon at 1988 emission levels

\section{CHARTS}

1. Carbon emissions

2. Prices per ton of emission and emission intensities

3. Energy prices and taxes for selected fuels

4. Carbon tax and tax revenue 


\section{INTRODUCTION AND SUMMARY}

Current levels of global greenhouse gas (GHG) emissions are likely to lead to global warming. To slow down, or eliminate, the threat of global warming, it is necessary to reduce emissions below current levels. As GHG emissions are increasing at a rate of about 2 per cent per annum this implies drastic reductions from the levels projected in the longer run.

Policy should aim at equating the marginal cost of reducing GHG emissions with the marginal benefits from avoiding global warming (1). However, little is known about the damages associated with climate change, so that the marginal benefits of avoiding climate change are difficult to estimate. The valuation of damages is further complicated because they are likely to occur only after several decades (OECD, 1991b). More is known about the cost of reducing GHG emissions, for which the future increase in fossil-fuel related $\mathrm{CO}_{2}$ emissions is of crucial importance (2).

Most OECD governments have expressed their willingness to reduce carbon dioxide $\left(\mathrm{CO}_{2}\right)$ emissions as part of policies to reduce the threat of global warming. It would make little sense for countries to introduce large carbon taxes unilaterally. A single country, even if it phased out its emissions completely, would not affect global warming (3). Therefore, negotiations on an international agreement to curb emissions are now under way under the auspices of the United Nations, and any agreement would then require governments to take action to implement the decisions. Taxes levied on the carbon content of fossil fuels ("carbon taxes") are being considered as one possible means of reducing such emissions. Sweden, Finland, Norway and the Netherlands have already introduced small carbon taxes.

Cross country experience suggests that in countries with high energy prices emission intensities are low. Emission intensities currently differ considerably as do energy prices, mainly because of large differences in taxation. Current taxes on oil products are already high in many OECD countries and represent an implicit carbon tax on oil products of over $\$ 200$ per ton of carbon in all the major European countries. The use of coal, on the other hand, is generally not taxed and in some countries it is subsidised. A reform of fossil-fuel taxation in line with carbon content would lead to a remarkable change in the structure of energy taxes.

Model simulations suggest that in order to achieve a significant reduction of future $\mathrm{CO}_{2}$ emissions, carbon taxes would need to be large. Simulations with OECD's GREEN model suggest that the carbon tax might need to rise to something like $\$ 300$ per ton of carbon in order to reduce $\mathrm{CO}_{2}$ emissions in the developed countries to 20 per cent below their 1990 level by 2020 . Estimates of the taxes required for such a reduction vary widely across different studies, as the simulated carbon taxes critically depend on a variety of parameter values, the size of which is difficult to determine empirically. A tax of $\$ 300$ per ton of carbon would be equivalent to a price increase of 
about $\$ 36$ on a barrel of oil and could yield tax revenues ranging from 3 to 7 per cent of GDP for different OECD countries. Revenues of this order of magnitude would be much larger than those currently collected from other forms of environmental taxation. Revenue neutrality could be ensured by reducing other taxes to match the carbon taxes.

\section{GLOBAL WARMING AND THE POLICY RESPONSE}

The International Panel on Climate Change (IPCC) recently submitted its report on the scientific assessment of climate change (IPCC, 1990). The build-up of greenhouse gases - the main ones being carbon dioxide $\left(\mathrm{CO}_{2}\right)$, chlorofluorocarbons (CFCs), methane $\left(\mathrm{CH}_{4}\right)$ and nitrous oxide $\left(\mathrm{N}_{2} \mathrm{O}\right)$ - associated with the Panel's "business-as-usual" projection points to a rise in global mean temperatures in the range of $0.2^{\circ} \mathrm{C}$ to $0.5^{\circ} \mathrm{C}$ per decade over the next century. According to the IPCC, slowing down the rate of warming to $0.1^{\circ} \mathrm{C}$ per decade would require more than a halving of GHG emissions from current levels (4).

World-wide energy-related emissions of $\mathrm{CO}_{2}$ - the most important GHG are currently almost 6 billion tons per year, with the OECD countries accounting for about half (Table 1) (5). If few or no steps are taken to curb energy-related emissions, the IPCC estimates that they will reach 25 billion tons by 2100 . Projections of emissions vary across global models. For example, Manne's (1991) estimate is 42 billion tons by 2100 , with the share of OECD countries in world emissions dropping to about 30 per cent by 2050 (Chart 1). There are also strong regional differences in the growth of $\mathrm{CO}_{2}$ emissions, with those in China likely to grow far more rapidly than those in OECD countries.

The 1988 climate change conference in Toronto suggested that countries should aim at a reduction of $\mathrm{CO}_{2}$ emissions by 20 per cent from the 1988 level by 2005 and by 50 per cent in the long run. A 20 per cent reduction from the 1988 level implies a reduction of close to 40 per cent compared to the business-as-usual development by 2005. Virtually all OECD countries have already expressed their willingness to limit their emissions and the reductions announced are in many cases close to the Toronto target (Table 2). Most countries aim either at a stabilisation of $\mathrm{CO}_{2}$ emissions at 1990 levels by early in the coming century or a reduction by 20 per cent. Currently the Inter-governmental Negotiating Committee (INC) is preparing a framework convention on climate change for possible signature at the 1992 United Nations Conference on Environment and Development.

While many countries have announced rather ambitious reduction targets, most have not yet legislated the means to reduce emissions. Discussion in Member countries to date has focused on improved information and regulatory measures aiming at improved energy efficiency and fuel switching. Governments appear to generally favour "command-and-control" solutions rather than economic instruments. While there seems to be scope to improve energy efficiency substantially (IEA, 1991a and Williams, 1990), regulatory measures are unlikely to be least-cost measures if adjustment possibilities differ significantly among energy users - as appears to be the case. Interest in the use of a "carbon tax" - a tax on the use of fossil fuels in direct proportion to their $\mathrm{CO}_{2}$ emissions - . has therefore increased, because it would give each energy user the same incentive to abate and leave the least-cost abatement decision to the individual. It would also give economic agents the right signals to search 
for new technological solutions. So far, only Finland, the Netherlands, Norway and Sweden have introduced limited carbon taxes, although many EEC countries have expressed their willingness to support a community-wide carbon tax.

\section{ENERGY PRICES, TAXES AND EMISSION INTENSITIES}

Man-made $\mathrm{CO}_{2}$ emissions are closely linked to the combustion of coal, oil and gas. These fossil fuels emit $\mathrm{CO}_{2}$ in certain relatively fixed proportions, with emissions per unit of energy being higher for coal than for oil and gas (Table 3). Emissions vary, therefore, with the amount of fossil fuel use and its mix. A reduction in emissions from fossil-fuel use can be achieved by:

a) a change in demand patterns and technology towards less use of energy; and

b) a change in the mix of fuels; the latter can take the form of substitution from fossil fuels with a high emission factor towards ones with a low one such as a switch from coal to gas or from fossil to non-fossil fuels (currently mainly hydro and nuclear energy).

The response of fossil-fuel demand and emissions to output and relative price changes depends crucially on energy technologies already embodied in existing capital. As there is usually little flexibility built into the existing capital stock, more efficient technologies in terms of energy use tend to change energy use only slowly. Time series analysis, therefore, shows low short-run price elasticities of fossil fuel use, while long-run elasticities vary considerably across empirical studies.

As energy prices have differed considerably among OECD countries for a long period of time, cross-country experience may provide a better gauge of the long-run effect of price differences on energy and emission intensities. There appears to be a strong inverse relationship between the implicit price of carbon emissions and emission intensities (Chart 2) (6). In North America, where the price per ton of emission is low on average, the emission intensity is high relative to other OECD countries. In Japan and some European countries with relatively high prices, emission intensities are much lower. A regression of emission intensities on prices per ton of emission implies an elasticity of -1.04 .

Chart 2 can be used as a rough guide to the magnitude of price increases which might be needed in different countries to reduce emission intensities by given amounts in the long run. It indicates that a wide dispersion of carbon tax rates across countries would probably be required in the case of equiproportionate emission cuts and that cutting emissions is likely to be cheaper in the countries where current prices are low and emission intensities high. This simple relationship suggests that increasing the U.S. price per ton of emission to the Japanese level, might eventually halve the emission intensity in the United States. This would still leave its emission intensity substantially higher than in Japan, owing inter alia to differences in climate, size of residential floor space and supply of mass transit facilities (MCDonald, 1990). Due to the apparent non-linearity of the relationship between price and emission intensity, halving the emission intensity in Japan would require a much sharper price increase than in the case of the United States. 
While prices of primary energy sources are determined in world markets, domestic consumer and producer prices differ significantly across countries mainly because of:

a) taxes (excise taxes and value-added taxes)

b) subsidies (grants, deficiency payments etc.); and

c) price-support measures (for instance, trade restrictions or special long-term agreements between coal producers and consumers).

Even after taking account of such policy measures, prices may differ among countries due to differences in refining and distribution costs as well as market structures.

Governments also influence emission intensities by energy conservation policies (e.g. grants for housing insulation, energy efficiency standards), by utility regulation (environmental regulations or restrictions on the supply of nuclear energy), by taxing energy-using goods (for instance, special car ownership fees) and through the provision of infrastructure (7). Objectives of energy policy have so far been mainly guided by energy security considerations, revenue objectives (financing of infrastructure) and social considerations (e.g. the desire to protect employment in coal industries in some European countries). Environmental measures have so far mainly impinged on coal-fired electricity plants so as to reduce emissions which cause acid rain.

The existing structure of energy taxes and subsidies in OECD countries already includes an implicit carbon tax which should be taken into account in any discussion of policy changes. There are some gaps in the information on taxation. Using the available partial information, Table 4 attempts to relate current taxes in 19 Member countries to the carbon content of the different fuels (8). Among the major OECD economies, the implicit carbon tax is low in North America, intermediate in Japan, Germany and the United Kingdom and high in France and Italy. For oil products, the implicit tax per ton of carbon is over $\$ 200$ in all the major European countries. The implicit taxes on specific products such as gasoline and diesel are generally higher still (9). Taxation of gas is much lower and -. with the exception of Sweden and Switzerland -. it is virtually non-existent for coal.

Pre-tax prices of most oil products differ little between countries, as would be expected for homogeneous goods which are readily available on world markets (Chart 3). Usually the ranking of end-use prices closely mirrors differences in taxation. There are, however, a few exceptions. In Japan and Finland, for instance, pre-tax prices of gasoline are much higher than in other countries, pointing to an important effect of trade restrictions or market imperfections (10). It is more difficult to compare national gas prices to a world market price, because of important differences in transportation and distribution costs.

End-use coal prices, while usually untaxed, differ by a large margin between countries owing to severe distortions in coal markets in many European countries (11) (Chart 3). Steenblik and Wigley (1990) have computed so-called producer subsidy equivalents for six countries, which show the amount of assistance to coal producers provided by taxpayers and consumers. The amount of subsidy and price support for coal producers is given in terms of the carbon content of coal in Table 4. Despite subsidisation, price support measures have kept prices artificially high in most of these countries. The effect of deregulation on coal prices and emission intensities is, however, difficult to 
predict: while a reduction in price support should reduce prices, the world market price may increase with the closing of inefficient mines; and utilities which have been obliged to buy high-priced domestic coal may opt for a different fuel.

\section{ENERGY PRICE EFEECTS OF A CARBON TAX}

Mechanically, a tax of $\$ 100$ per ton of carbon would add $\$ 12$ to the price of a barrel of oil. The same tax would more than double the steam coal price in 1988 from $\$ 44$ per metric ton of coal to about $\$ 104$. The gas price would rise by about 60 per cent from its value in 1988 (Panel A of Table 5). To put such increases in fossil-fuel prices into context, the real prices of fuels, especially oil and gas, have varied substantially during the $1980 \mathrm{~s}$. The price of oil reached a peak in 1981 at about $\$ 50$ per barrel (1990 prices). The difference of almost $\$ 30$ per barrel between the average crude oil price in 1981 and 1990 is equivalent to a tax of about $\$ 245$ per ton of carbon.

The mechanical effect of a $\$ 100$ tax on end-use prices - assuming no change in current taxation -. would vary substantially across countries and fuels. As shown in the previous section, end-use prices of different fuels differ considerably among countries so that the addition of the same absolute amount of tax would raise. prices by widely differing percentages (Panel $B$ of Table 5). End-use prices would increase most in the United States and - - apart from the coal price - the least in Japan among the three largest countries. The large differences in end-use prices mainly reflect the effects of existing energy policies, which are only to a minor extent geared towards internalising the external cost of fuel use.

Carbon taxes have recently been introduced in Sweden, Finland, Norway and the Netherlands. The Swedish carbon tax is the largest so far and part of a package to internalise the externalities from fossil-fuel use. Existing energy taxes on oil products were halved, while a carbon tax was added. In addition, the sulphur content of different fuels has been taxed. The tax reform has only a small effect on most oil product prices but has lead to increases in gas and coal prices (Table 6).

Bringing the structure of fossil-fuel taxation more in line with environmental considerations would lead to changes in relative prices. As the Swedish tax reform shows, taxation of coal would increase, while there would still be price increases for gas and some low-taxed oil products. Fuel switching following such a tax change might result in a sizeable reduction of $\mathrm{CO}_{2}$ and other emissions from fossil-fuel use (12).

Chart 2 can also be used as a guide to the long-run effect of the imposition of a $\$ 100$ tax per ton of carbon. Were the price per ton of carbon in the U.S., for instance, to increase from its level of $\$ 207$ in 1988 to $\$ 307$ and stay there in real terms, a fall in the emission intensity of 34 per cent could be expected over the longer term. The same price increase would reduce emission intensities by only 22 per cent for countries like Germany or the United Kingdom. For countries like Switzerland and Norway, where 1988 base prices are still higher and emission intensities lower, a reduction of only 15 per cent would be achieved. An OECD-wide $\$ 100$ carbon tax might reduce emissions by about 25 per cent. 
The size of carbon taxes required to achieve certain emission targets has been analysed in several studies (see Barrett, 1990; Nordhaus, 1990 and Hoeller et al., 1991). The studies show that the tax has to be sizeable and to increase over time, just to stabilise emissions at the current level. The tax rates estimated to be necessary for the stabilisation of emissions at the 1990 level by the end of 2020 , range from $\$ 30$ to $\$ 150$ per ton of carbon. The level of tax for a 20 per cent reduction would be considerably higher, and vary considerably among regions. Model simulations with OECD's GREEN model suggest, that carbon taxes may have to rise to $\$ 209, \$ 213$ and $\$ 955$ for North America, Europe and the OECD's Pacific region, respectively, to achieve such an emission constraint (Burniaux et al. 1991 and 1991a). For North America and the OECD's Pacific region, such carbon taxes are roughly in line with the historical cross-country pattern as, shown in Chart 2. For Europe the chart would suggest somewhat higher carbon taxes. The chart would also suggest that a wide dispersion of tax rates could be expected in Europe and the Pacific region in the case of an equiproportionate emission constraint.

The large differences in tax levels between the studies reflect different assumptions about substitution possibilities, technological developments and the aggregate repercussions of the introduction of a carbon tax. Sensitivity analyses using OECD's GREEN model or the work by Edmonds and Barns (1990) show that assumptions concerning energy prices, income elasticities, inter-fuel substitution elasticities and energy efficiency improvements explain much of the differences. Varying these parameters in a range consistent with empirical studies can easily double or halve tax rates.

Currently the supply of non-fossil fuels (at present mainly hydro and nuclear power) is limited because of physical and environmental considerations. With a sharp increase in fossil-fuel end-use prices, it is 1ikely that research could lead to a major expansion of the use of non-fossil fuels (for instance, solar energy). Such "backstop" technologies are usually assumed to come on stream early in the next century. The supply price of backstop technologies puts an upper cap on the carbon tax needed to achieve emission targets; fossil fuel use could be expected to decline following the penetration of energy markets by backstop energy sources.

\section{THE REVENUE POTENTIAL OF A CARBON TAX}

The potential revenue implications of the introduction of a $\$ 100$ tax per ton of carbon, assuming no change in existing energy taxation and ignoring any second-round effects, are shown in Table 7. The size of the hypothetical tax take is considerable, ranging between 2 and 25 per cent of the actual 1988 tax revenues in different OECD countries. The revenues raised by a $\$ 100$ carbon tax could account for over 10 per cent of total tax revenues raised by taxes on goods and services or on income in many countries, and in some it could be as much as a quarter or more.

\section{i) Equiproportionate cuts in emissions}

The tax rates and hence the revenues associated with equiproportionate $\mathrm{CO}_{2}$ emission reductions of the sort set out by the Toronto conference would range widely across regions. The preliminary results of the OECD's GREEN model suggest that achieving a 20 per cent cut in emissions in the developed countries by 2010 and stabilising emissions thereafter, would require taxes of about $\$ 200$ per ton of carbon in 2020 for North America and Europe and $\$ 950$ for 
the Pacific region (13) (Chart 4). These tax rates imply tax revenues of approximately 3,4 and 7 per cent of GDP at factor cost for North America, Europe and the OECD's Pacific region, respectively. The large difference in tax rates points to the fact that the costs of abatement differ considerably between regions.

Other models give a wide range of results, although tax rates and hence revenues are always substantial. For a similar amount of emission reduction, model simulations by Manne (1991) give a tax revenue of about 3 per cent of GDP for the United States and over 1 per cent of GDP for the other OECD countries. Simulation results using the IEA's model point to a much higher tax rate and tax revenue for the United States and Europe (IEA, 1991).

While most simulation exercises assume revenue neutrality, revenues are usually rechanneled in a lump-sum fashion. Aggregate welfare effects, which in al1 studies exclude benefits from avoiding climate change, may therefore be lower than suggested in these studies, if the revenue raised via a carbon tax is used to lower other distorting taxes. Poterba (1990) argues that the deadweight loss from small carbon taxes is much lower than that of other major revenue sources.

\section{ii) Setting a price per ton of emission globally}

A system of emission trading between countries or regions or a global carbon tax would allow cuts in emissions to be concentrated in countries where abatement is cheapest, so that world-wide welfare losses would be smaller than in the case of unilateral regional reductions (Burniaux et al, 1991). For the same global emission constraint, the carbon tax and, in the case of trading, the price per ton of emission could be expected to be the same across countries. However, there are many differences in the way in which each type of instrument operates in practice. In the case of a carbon tax the price increase per ton of carbon is set beforehand and the outcome in terms of abatement is uncertain, while in the case of emission trading, the emission constraint is fixed and it is the price which is uncertain. In addition, in the case of a carbon tax the revenue accrues to the government, while there are many possibilities to allocate emission permits initially. Also the revenue flows associated with the sale of permits between countries could be large in the case of a permit trading system. Therefore, while the two alternatives are equivalent in efficiency terms, welfare consequences for different regions and countries are importantly influenced by the specific type of agreement.

Using the same global constraint on $\mathrm{CO}_{2}$ emissions as in the simulation reported above, preliminary results of GREEN again suggest that a sizeable price per ton of carbon would be required by 2020 . However, it would be lower than the global average tax rate in the equiproportionate reduction case considered above as abatement takes place. where it is cheapest. This implies a selling of emission rights from China and the USSR to the OECD region and the energy-exporting LDCs. The price per ton of carbon would thus be lower than before in the OECD regions and the energy-exporting LDCs, but it would be higher in China and USSR. The global amount of revenue under such a scheme would again be substantial and the regional transfers implied could be several times larger than existing official aid flows. 
However, there are important practical problems concerning the implementation of permit schemes. One suggested alternative is a global tax system, where the receipts would be collected by an international agency and the money refunded to countries on a per-capita (or per-adult) basis. Such an arrangement would mainly benefit developing countries and is seen as an incentive for them to participate in an international agreement. Since the problem is clearly a global one, it would be important to ensure that the issue of free riders was addressed and maximum participation was obtained. The way in which this would be done would have strong implications for the level of international transfers and the fiscal position of individual countries. 


\section{NOTES}

1. Apart from the adverse effects of climate change, there are other externalities from fossil-fuel use (for instance, damage by acid rain caused by $\mathrm{SO}_{2}$ emissions) which should in principle be reflected in the relative prices of fuels.

2. Emissions of other GHGs -- mainly methane and nitrous oxide - should not be neglected, although it is difficult to devise policy instruments to reduce such emissions, as sources of methane and nitrous oxide are diverse and emission rates uncertain. The use of most CFCs will be banned by the year 2000. With the phase-out of CFCs, the contribution of man-made $\mathrm{CO}_{2}$ emissions to the global warming potential could rise to over 70 per cent.

3. Even for the OECD countries together, it would be impossible to reduce global $\mathrm{CO}_{2}$ emissions significantly, as a virtual phase-out of fossil fuel use in OECD countries would be outweighed by increases in non-OECD countries over the next decades (Edmonds and Barns, 1990). In addition, export competitiveness would suffer in the case of unilateral action, at least in the short run, and imports of energy-intensive goods - - if untaxed - would increase sharply. If energy-intensive sectors of production were to shift location to countries with relatively low or no carbon taxes, global emissions could even increase. These considerations have made countries so far reluctant to introduce large carbon taxes unilaterally.

4. The links between emissions, concentration of GHGs and global warming are discussed in OECD (1991a). Global warming is caused by the increasing concentrations of GHGs in the atmosphere which slow the release of earths energy radiation into space. Once emitted, GHGs remain in the atmosphere for decades to centuries. For example, $\mathrm{CO}_{2}$ emissions are estimated to stay in the atmosphere 50-200 years. The wide range arises from uncertainties concerning absorption rates of natural sinks. Because the gases remain so long in the atmosphere stabilising current emissions would only slow the increase of concentration levels. $\mathrm{CO}_{2}$ concentrations could rise by up to 440-500 parts per million by 2100 from the present level of about 350 parts per million. This alone could cause a rise of global temperatures by $1{ }^{\circ} \mathrm{C}$. To stabilise concentrations at the present level would need a 50-80\% cut of $\mathrm{CO}_{2}$ emissions. Apart from uncertainties surrounding the link between emissions and concentration levels, warming associated with certain concentration levels is difficult to model as feedback effects from oceans, clouds and ecosystems are poorly understood.

5. In addition, deforestation in tropical zones currently adds about 20 per cent to world-wide emissions. In principle, any agreement on $\mathrm{CO}_{2}$ emission reductions should take account of the emissions from deforestation.

6. The data in the Charts are based on IEA data for energy prices, fossil fuel use and emissions. In order to calculate economy-wide prices per 
ton of emission, fuel prices per ton of oil equivalent are weighted by emission factors.

7. Present energy policies in Member countries are described in IEA (1990).

8. While $\mathrm{CO}_{2}$ is emitted when fossil fuels are burned, taxes are expressed per ton of carbon; 3.7 tons of $\mathrm{CO}_{2}$ are equivalent to one ton of carbon emitted.

9. Road transport is also a significant source of pollution apart from generating GHGs, giving rise to lead emissions, low-level ozone creation, acid rain and noise. Another externality from road transport is congestion. All these externalities would argue in favour of relatively high taxes on automotive fuels, even in the absence of the threat of global warming (Pearson and Smith, 1990).

10. Price distortions in domestic fuel markets are also likely to be large in many non-Member countries. The benchmark data of OECD's GREEN model which refers to 1985 suggests that fossil fuel prices in the USSR, China and India are respectively less than a quarter and about a half of those in North America, with particularly large distortions for coal in all three countries. Until recently the same also applied to Poland, Hungary and the CSFR, where prices for different fuels were usually less than half those in Germany. Low prices are likely to have been an important reason for the higher pollution intensities in those countries. Calculations by Unterwurzacher and Wirl (1991) suggest that raising fuel prices in Poland, Hungary and the CSFR to German levels could reduce $\mathrm{CO}_{2}$ emissions by approximately 30 per cent from the 1990 levels.

11. Apart from $\mathrm{CO}_{2}$ emissions, nitrogen oxides (NOx) and sulphur dioxide $\left(\mathrm{SO}_{2}\right)$ emissions from coal burning -- important contributors to acid rain - would argue for additional taxes on coal. An $\mathrm{SO}_{2}$ emission charge for coal fired utilities exist in France and Sweden while the United States recently introduced a permit trading system for utilities. In most countries, utilities face rather stiff regulatory measures for reducing emissions of pollutants other than $\mathrm{CO}_{2}$. These measures are estimated to increase investment outlays for new coal-fired plants by 30 to 35 per cent (IEA, 1988). While the cost of regulatory measures also affects relative fuel prices, it is difficult to estimate cost wedges in the absence of detailed plant data.

12. There is strong compelentarity between different emissions. The interaction between abatement of different emissions from fossil fuel use has been highlighted in several studies. Glomstod et al. (1990) have shown in model simulations for Norway that the introduction of a carbon tax would reduce emissions of sulphur dioxide, nitrogen oxides, carbon monoxide and particulates roughly in line with the reductions of $\mathrm{CO}_{2}$. While the reduction of $\mathrm{CO}_{2}$ emissions by 26 per cent by 2010 would reduce the Norwegian GDP by 2.7 per cent below baseline, benefits from reducing other pollutants and from cutting traffic accidents and traffic noise would offset roughly two-thirds of the GDP loss due to the $\mathrm{CO}_{2}$ emission ceiling. Bergman (1990) calculates that the sharp emission reductions for sulphur dioxide and nitrogen oxide emissions between 1980 
and 1993 to which the Swedish government is committed, may lead to a stabilisation of $\mathrm{CO}_{2}$ emissions at their 1980 level. In the absence of reductions in other pollutants, $\mathrm{CO}_{2}$ emissions might have grown at a rate of 3 per cent per year.

13. The simulation reported here assumes a) $\mathrm{CO}_{2}$ emissions in the OECD regions and in the USSR would be restricted to 80 per cent of their 1990 levels by 2010, and stabilised thereafter; and b) emissions in the energy-exporting LDCs and China would be restricted to being 50 per cent higher than their 1990 levels by 2010, and stabilised thereafter. The large difference in carbon taxes between the Pacific region and North America and Europe is largely explained by the much higher fossil fuel prices in the Pacific region in the baseline (see also Chart 2) and the faster GDP growth in the Pacific than in the other OECD regions. 


\section{REFERENCES}

BARRETT, S. (1990), "Economic instruments for climate change policy", ENV/EC(90)33/ANN1, Paris, December.

BERGMAN, L. (1990), "Energy and environmental constraints on growth: a CGE modeling approach", Journal of Policy Modeling, 12(4).

BURNIAUX, J-M., J. Martin, G. Nicoletti and J. Oliveira-Martins (1991), "The costs of policies to reduce global emissions of $\mathrm{CO}_{2}$. Initial simulation results with GREEN", OECD, Department of Economics and Statistics Working Paper No. 103, June.

BURNIAUX, J-M., J. Martin, G. Nicoletti and J. Oliveira-Martins (1991a), "Green - A multi-sector, multi-region dynamic general equilibrium model for quantifying the costs of curbing $\mathrm{CO}_{2}$ emissions: A technical manual", OECD, Department of Economics and Statistics Working Paper No. 104, June.

EDMONDS, J. and D.W. Barns (1990), "Factors affecting the long-term cost of global fossil fuel $\mathrm{CO}_{2}$ emissions reductions", mimeo., Washington, December.

GLOMSR $\emptyset$ D, S., T. Johnsen and H. Vennemo (1990), "Stabilisation of emissions of $\mathrm{CO}_{2}$ : a computable general equilibrium assessment", Discussion Paper No. 48, Central Bureau of Statistics, Oslo, April.

HOELLER, P., A. Dean and J. Nicolaisen (1991), "Macroeconomic implications of reducing greenhouse gas emissions: a survey of empirical studies", OECD EConomic Studies, No. 16, Spring.

IEA (1988), Emission Controls in Electricity Generation and Industry, Paris.

IEA (1990), Energy Policies and Programmes of IEA Countries, 1989 review, Paris.

IEA (1990a), Energy prices and taxes, Paris.

IEA (1991), "World energy outlook to 2005", background paper, Paris, March.

IEA (1991a), Greenhouse Gas Emissions: The Energy Dimension, Paris

IEA (1991b), "Energy and the environment: transport system responses in the OECD", Paris (forthcoming).

INTERGOVERNMENTAL PANEL ON CLIMATE CHANGE (IPCC) (1990), "Policymakers summary of the scientific assessment of climate change", WMO and UNEP, New York, June.

MCDONALD, S.C. (1990), "A comparison of energy intensity in the United States and Japan", Pacific Northwest Laboratory, Washington. 
MANNE, A. (1991), "Global 2000: Three scenarios for reducing carbon emissions", paper presented at the OECD's Comparative Modelling Exercise in Washington, mimeo., March.

NORDHAUS, W.D. (1990), "A survey of estimates of the cost of reduction of greenhouse gas emissions", mimeo., February.

OECD (1990), Revenue Statistics of OECD Member Countries, Paris.

OECD (1991), "Estimation of greenhouse gas emissions and sinks", background report for OECD Experts Meeting, 18-21 February 1991, Paris.

OECD (1991a), The State of the Environment, Paris.

OECD (1991b), "Estimating the benefits of greenhouse warming abatement", ENV/EC/ECO(91) 3 (forthcoming).

PEARSON, M. and S. Smith (1990), "Taxation and environmental policy", IFS Commentary No. 19, The Institute for Fiscal Studies, January.

POTERBA, J.M. (1990), "Designing a carbon tax", Massachusetts Institute of Technology, mimeo, September.

STEENBLIK, R.P. and K.J. Wigley, (1990), "Coal policies and trade barriers", Energy Policy, Vol. 18, No. 4, May.

UNTERWURZACHER, E. and F. Wirl (1991), "Wirtschaftliche und politische Neuordnung in Mitteleuropa: Auswirkungen auf die Energiewirtschaft und Umweltsituation in Polen, der CSFR und Ungarn", Zeitschrift fur Energiewirtschaft, (forthcoming).

WILLIAMS, R.H. (1990), "Low-cost strategies for coping with $\mathrm{CO}_{2}$ emission limits", The Energy Journal, Vol. 11, No. 3, pp. 35-59. 


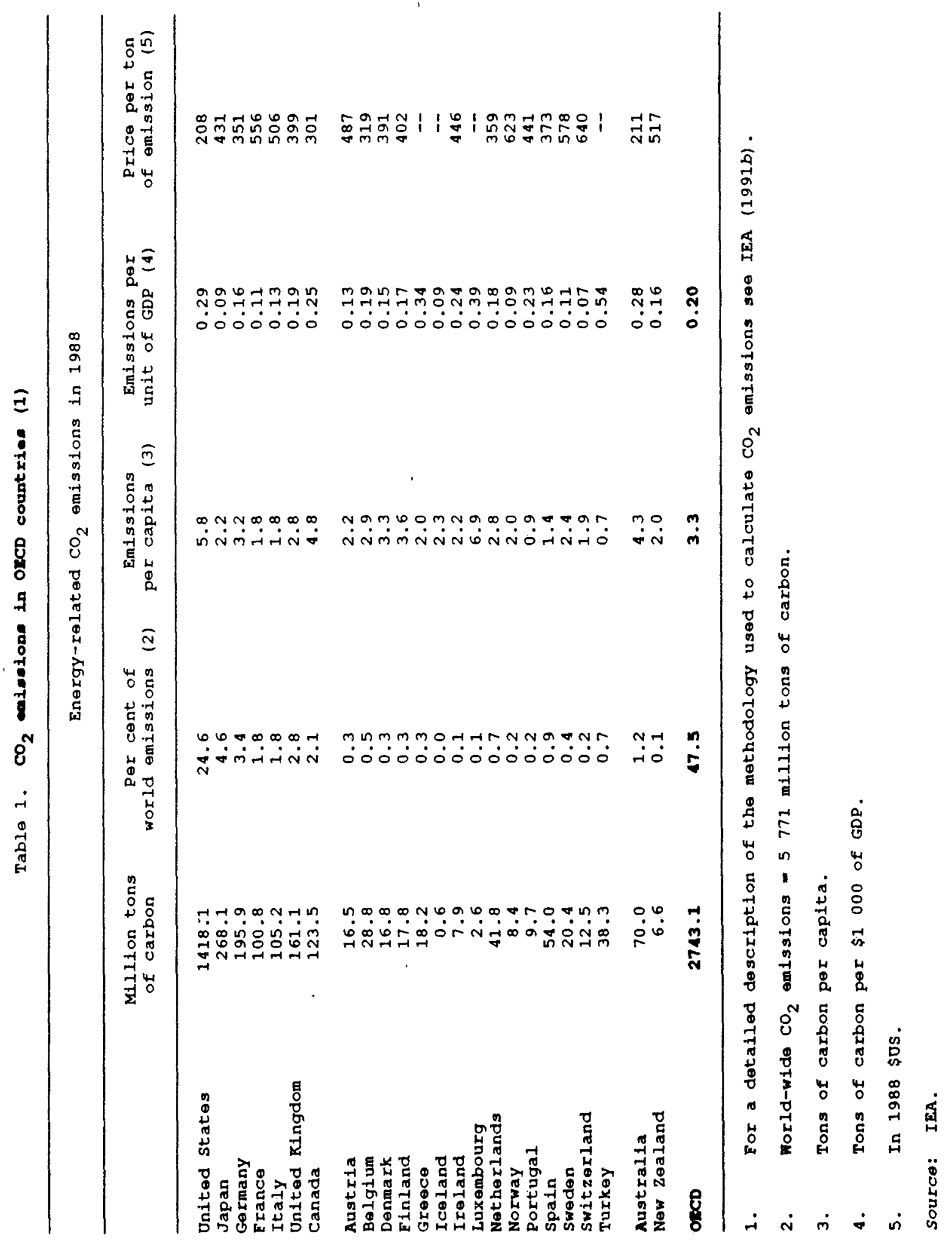




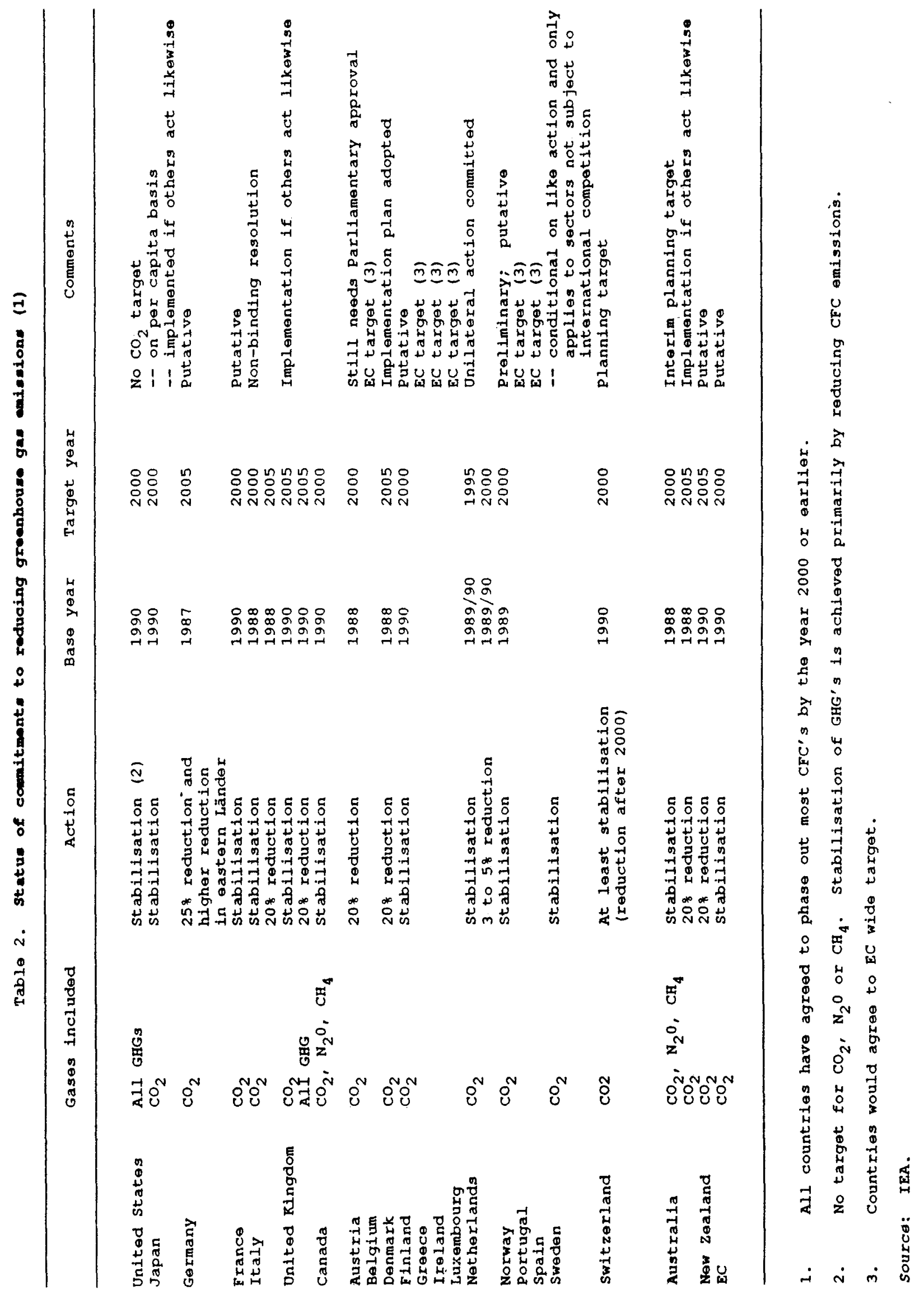


Table 3. Carbon content and carbon emission coefficients (1)

\begin{tabular}{lcc}
\hline & $\begin{array}{c}\text { Gram of carbon } \\
\text { per megajoule }\end{array}$ & $\begin{array}{c}\text { Ton of carbon per } \\
\text { ton of oil equivalent }\end{array}$ \\
\hline $\begin{array}{l}\text { Heavy fuel oil } \\
\text { Light fuel oil }\end{array}$ & $20-21$ & $0.80-0.84$ \\
$\begin{array}{l}\text { Gasoline } \\
\text { Diesel }\end{array}$ & $19-20$ & $0.76-0.80$ \\
Coal & & $0.96-1.00$ \\
Gas & $24-25$ & $0.56-0.64$ \\
Peat & $14-16$ & $1.10-1.20$ \\
Wood & $28-30$ & $1.20-1.30$ \\
Wastes (solid) & $29-33$ & $20-1.80$ \\
\hline
\end{tabular}

1. One ton of carbon corresponds to 3.7 tons of $\mathrm{CO}_{2}$.

Source: OECD (1991), Estimation of Greenhouse Gas Emissions and Sinks, Paris. 


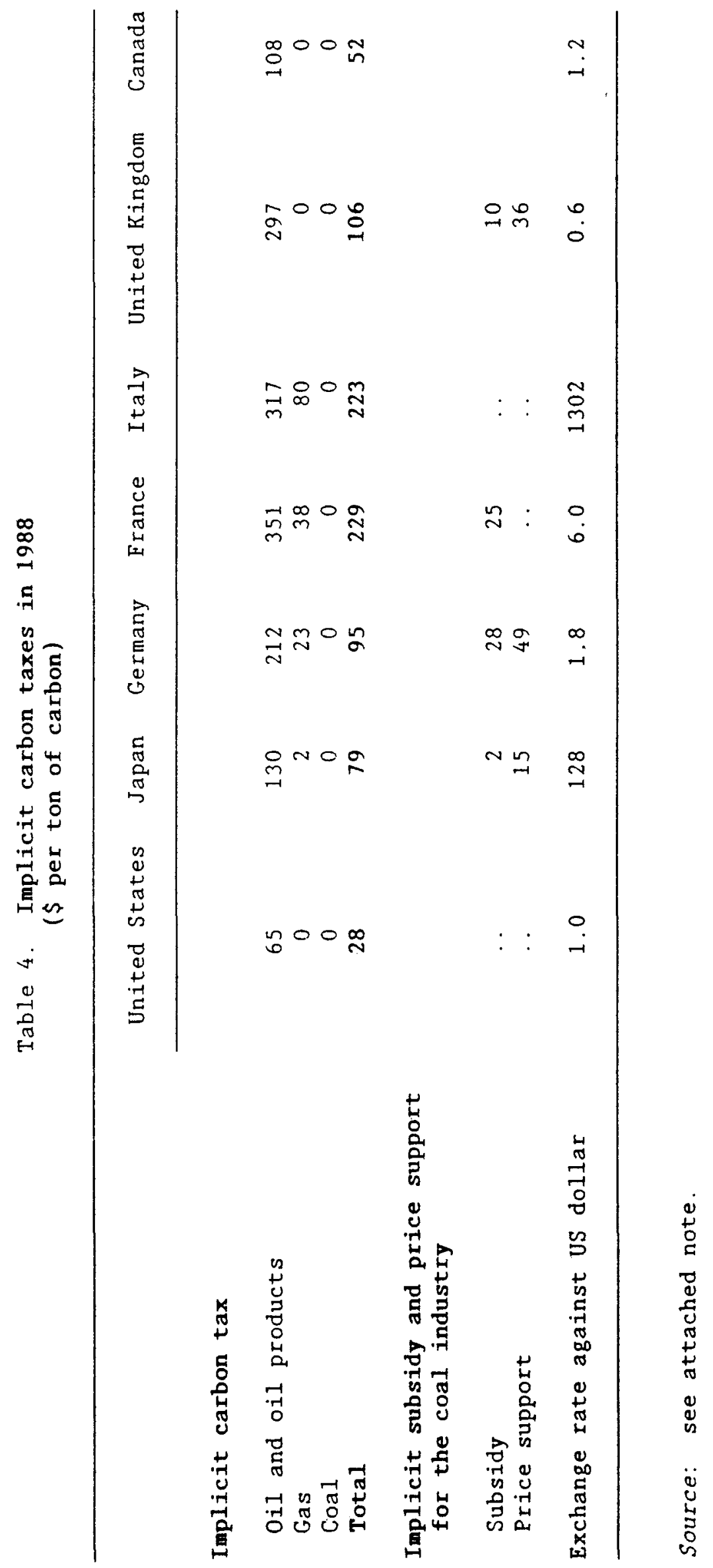




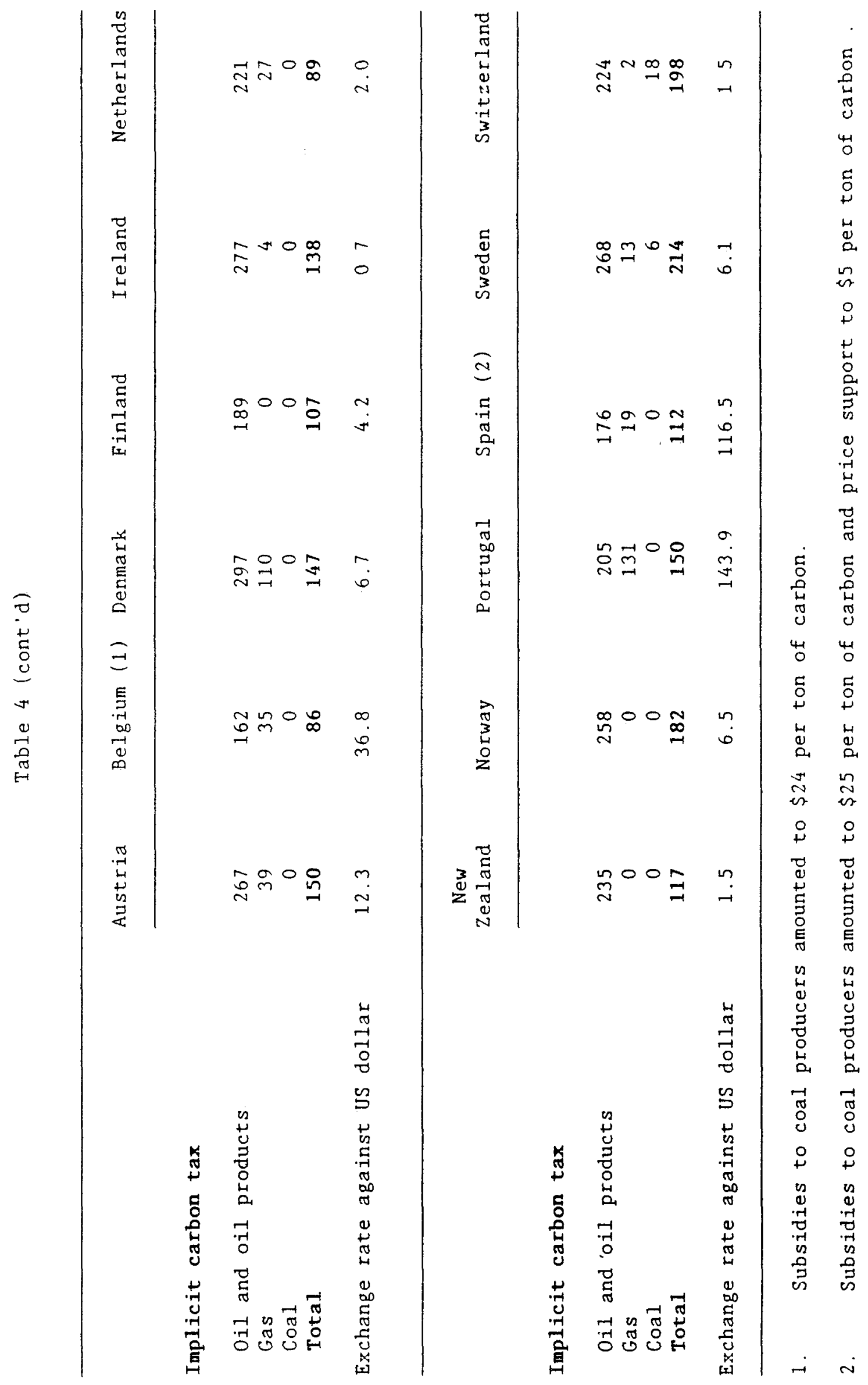




\section{Note to Table 4}

The numbers in the table are a crude attempt to relate existing taxes and subsidies to $\mathrm{CO}_{2}$ emissions from different energy sources. The calculations are based on the price and tax numbers in IEA (1990a), the underlying energy consumption matrix and estimates for assistance to coal producers.

The taxation numbers for the different fuels (gasoline, diesel, light and heavy fuel oil in the case of oil products) include excise taxes and VAT for households. However, a split between household and business consumption of diesel and gasoline is not possible. The calculations assume that all gasoline is consumed by households (includes VAT) and all diesel is used by businesses (excludes VAT). Additional taxes on electricity consumption (mainly VAT) have not been taken into account, but taxation of fossil-fuel primary energy inputs into electricity production has been. For the United States, local taxes on fossil fuel use are not available in IEA (1990a). An estimate for import duties for Japan and the United States is included. Small import duties in Austria, Finland and Portugal are not taken into account. In a few instances - such as taxes on natural gas for residential use in the United States, taxes on steam coal for industrial use in Canada and taxes on natural gas and steam coal for electricity generation for most countries -. tax numbers are not available: in these cases a zero tax is assumed. Where tax or price numbers were available in previous years, but not for 1988, an estimate for the tax and price numbers for 1988 has been made.

Producer subsidy equivalents (PSEs) for the coal industry are only available for Japan, Germany the United Kingdom, Belgium and Spain. The methodology for constructing PSEs for the coal industry is described in Steenblik and Wigley (1990). The data for the calculations in Table 5 include direct and indirect aid to current production and price support, but exclude assistance not benefiting current production. The French number is a subsidy (excluding assistance to miners' pensions) based on Charbonnage de France data (for 1990). That no numbers are shown for other coal producing countries does not imply that subsidies do not exist. There are also no numbers available on assistance to the oil and gas industries. 

Table 5. The wohenical effect of a $\$ 100$ tex per ton of enbos on energy prione
$(\$ 08,1988)$

A. Price effect on prinery energy vourcan

\begin{tabular}{|c|c|c|c|}
\hline & Crude Oil & Coal & Natural Gas \\
\hline Unit of measure & Barrel & $\begin{array}{l}\text { Metric } \\
\text { ton }\end{array}$ & $\begin{array}{l}\text { Ton of oil } \\
\text { equivalent }\end{array}$ \\
\hline $\begin{array}{l}\text { Tons of carbon/unit of fuel } \\
\text { World market price (\$) } \\
\text { Absolute tax (\$) } \\
\text { Price increases, per cent }\end{array}$ & $\begin{array}{l}0.12 \\
14.9 \text { (1) } \\
12.0 \\
81 \%\end{array}$ & $\begin{array}{l}0.61 \\
44.0(2) \\
60.5 \\
138:\end{array}$ & $\begin{array}{l}0.60 \\
95.0(3) \\
60.0 \\
638\end{array}$ \\
\hline
\end{tabular}

B. Price effect on end-use prices (per ton of ofl oquivalent)

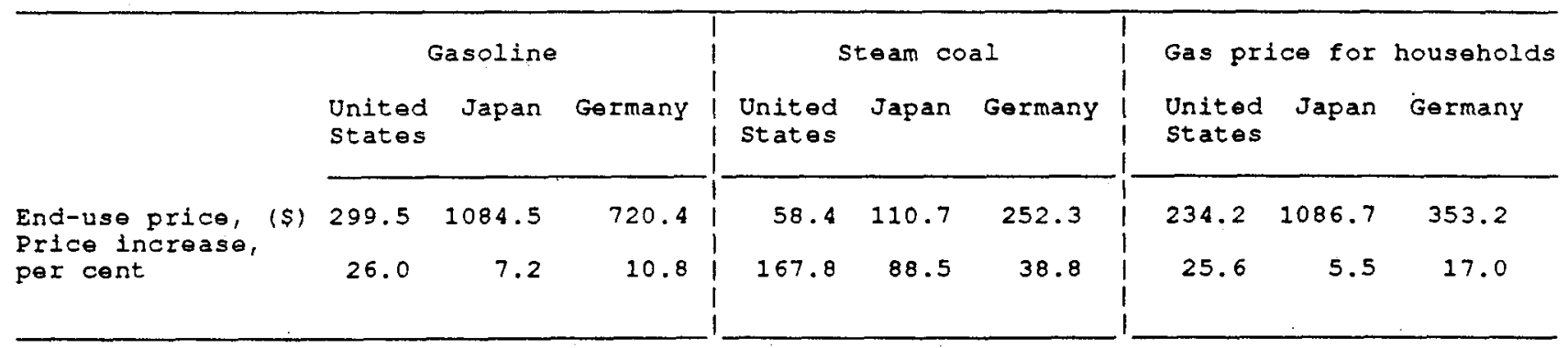

1. IEA country average import price.

2. OECD average steam coal import price.

3. EEC average import price by pipeline.

Source: IEA (1990a), Energy Prices and Taxes, paris. 


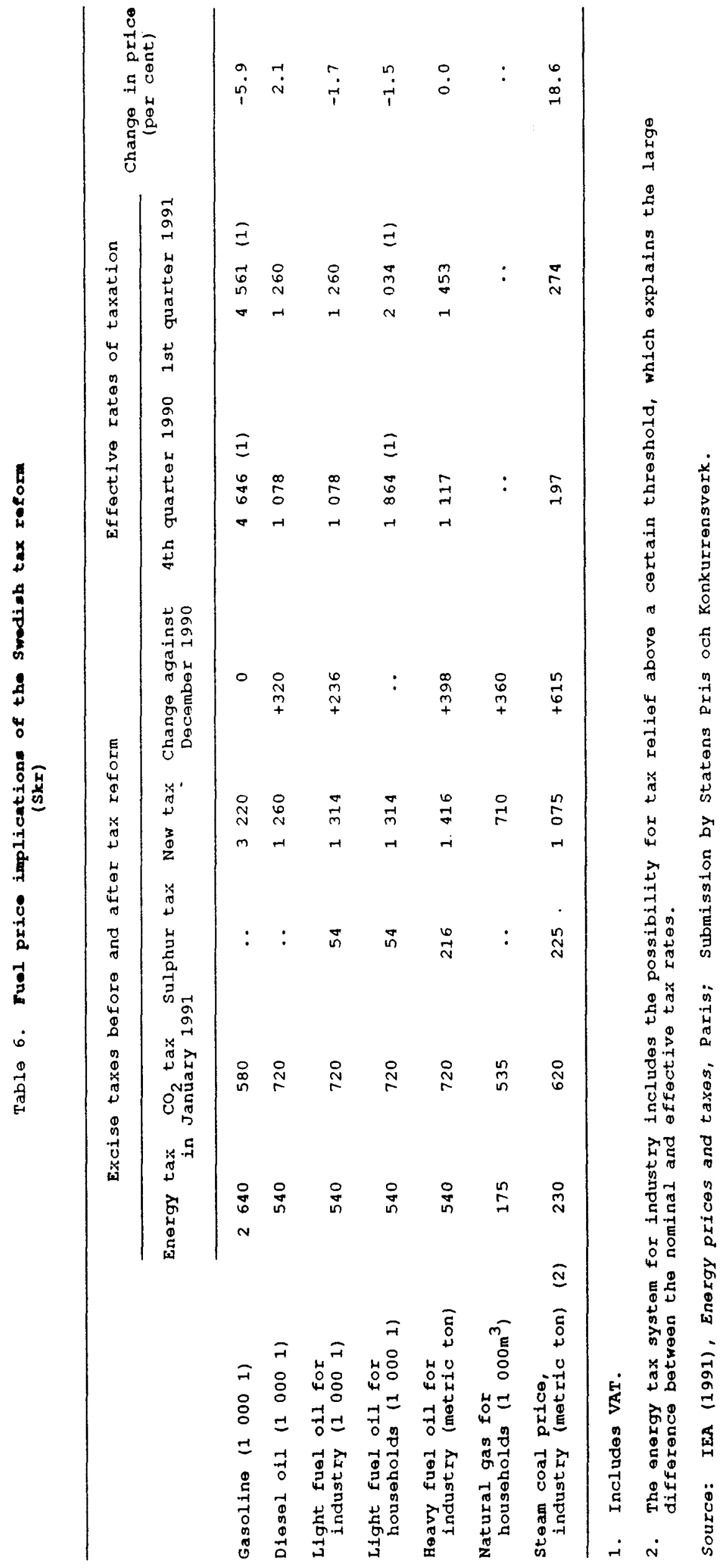


Table 7. Tax revenue of a $\$ 100$ tax per ton of carbon at 1988 emission levels

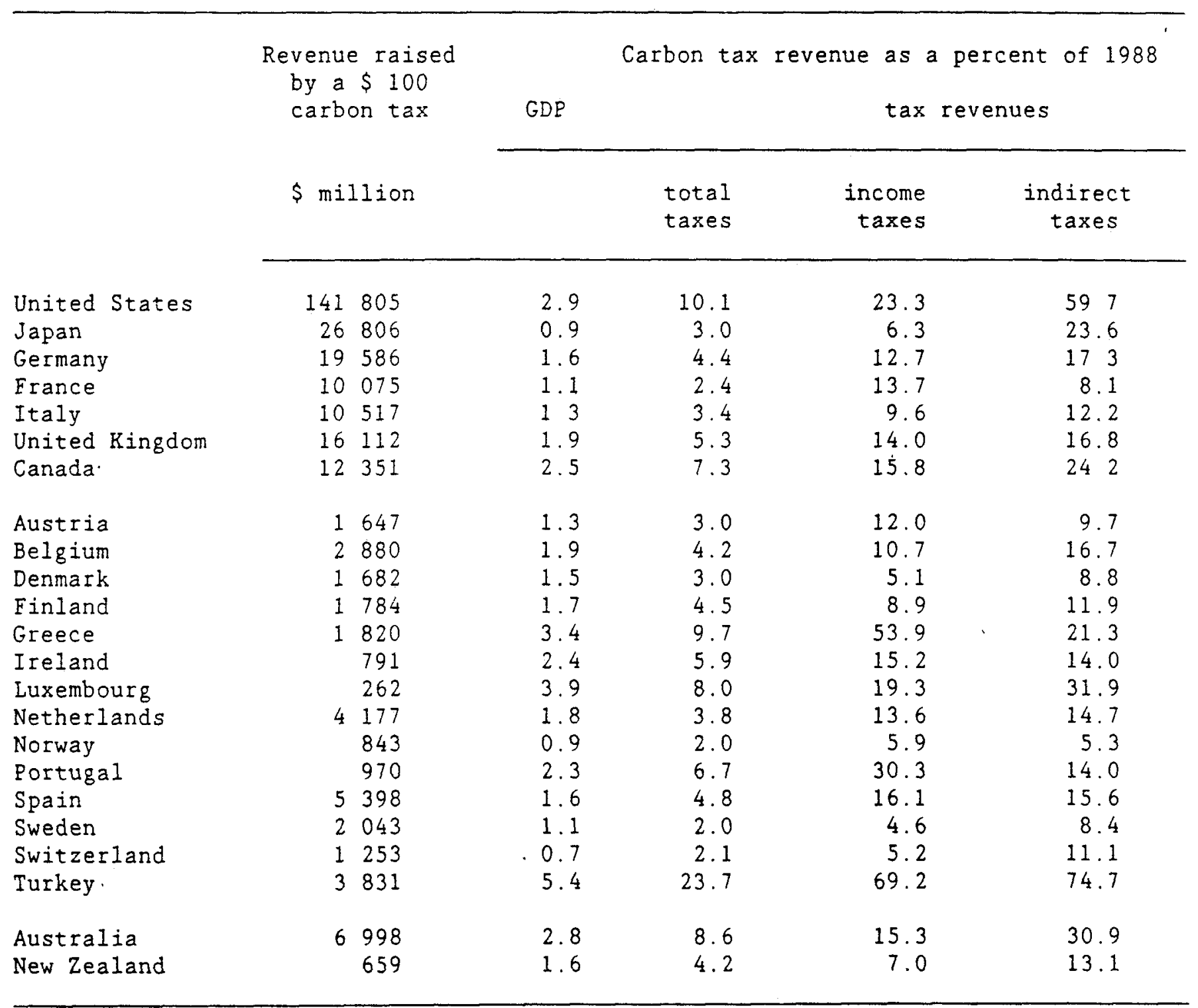

Source: OECD, Revenue Statistics of OECD Member Countries. 
Chant 1

\section{Carbon emissions}

(business-as-usual scenario)

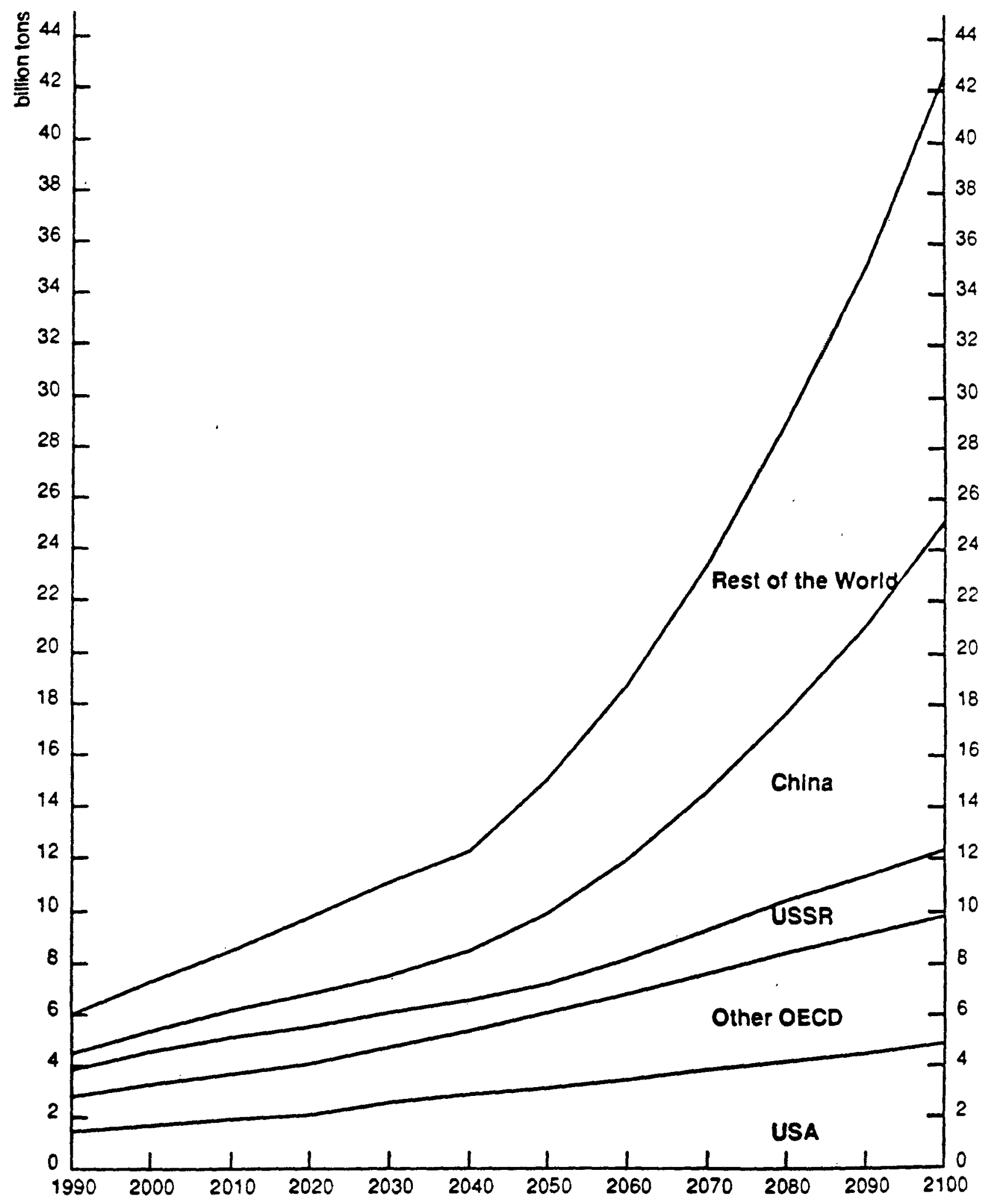

Source: Manne (1991). 
Chart 2

Prices per ton of emission and emissions intensities (1988, \$ US)

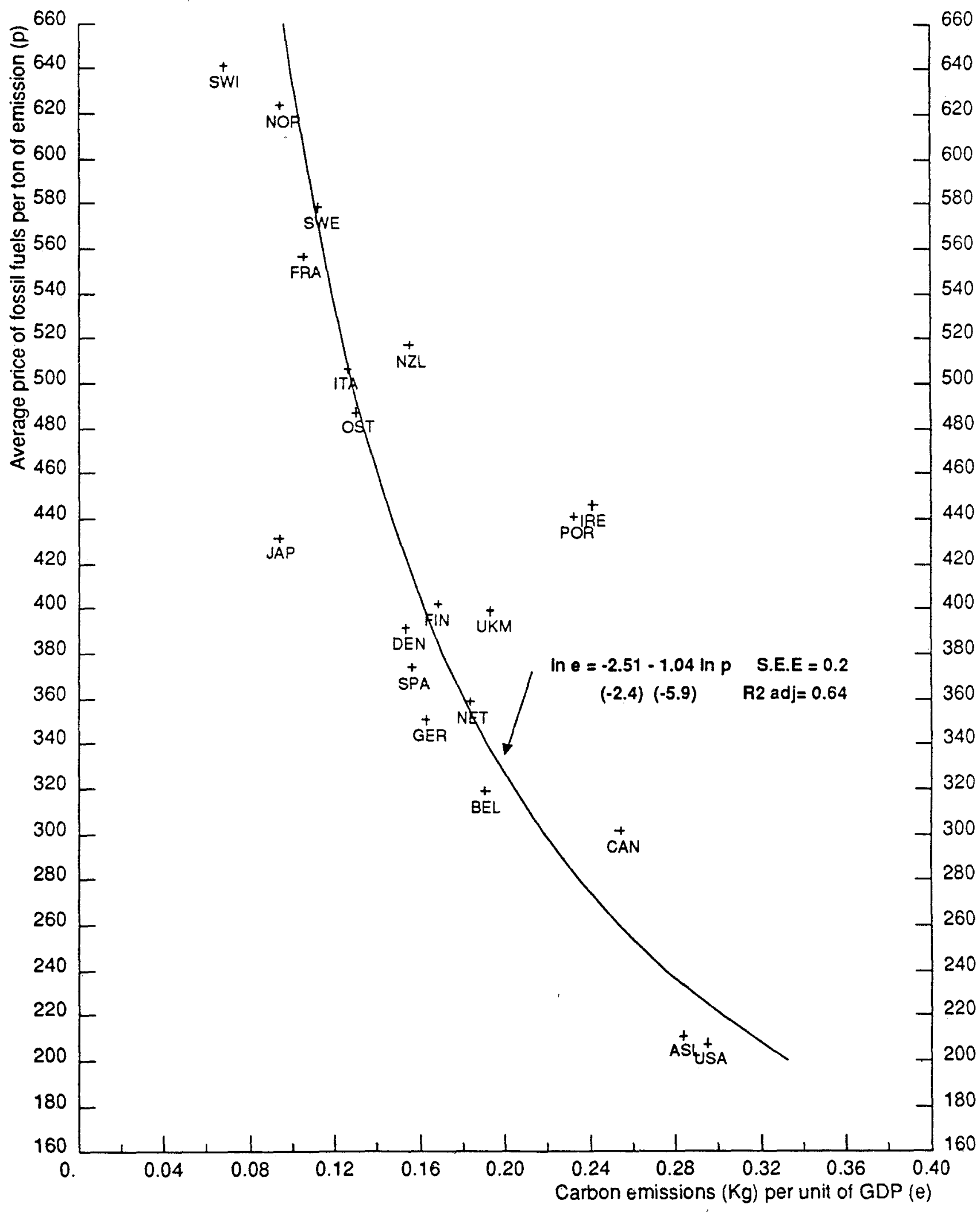

Source: IEA (1990a and 1991b). 
Criart 3

Energy prices and taxes for selected fuels

(US dollars per ton of oil equivalent, 1988)

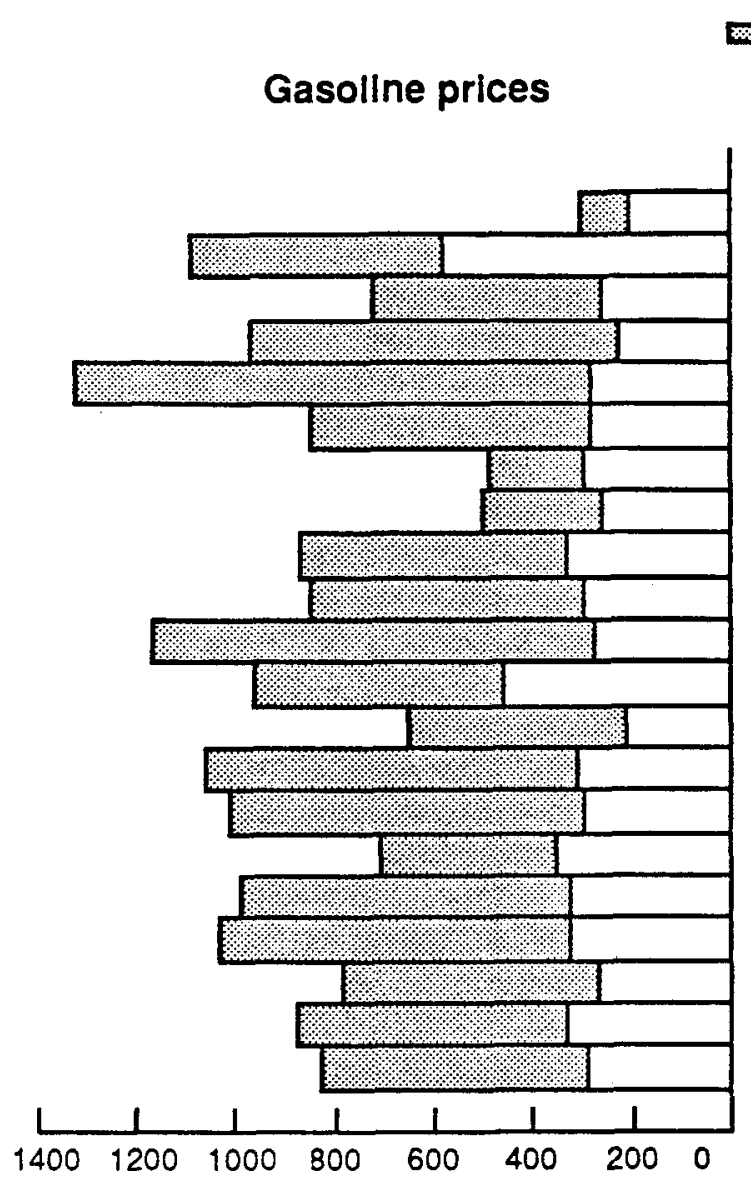

Tax component

Natural gas prices for households

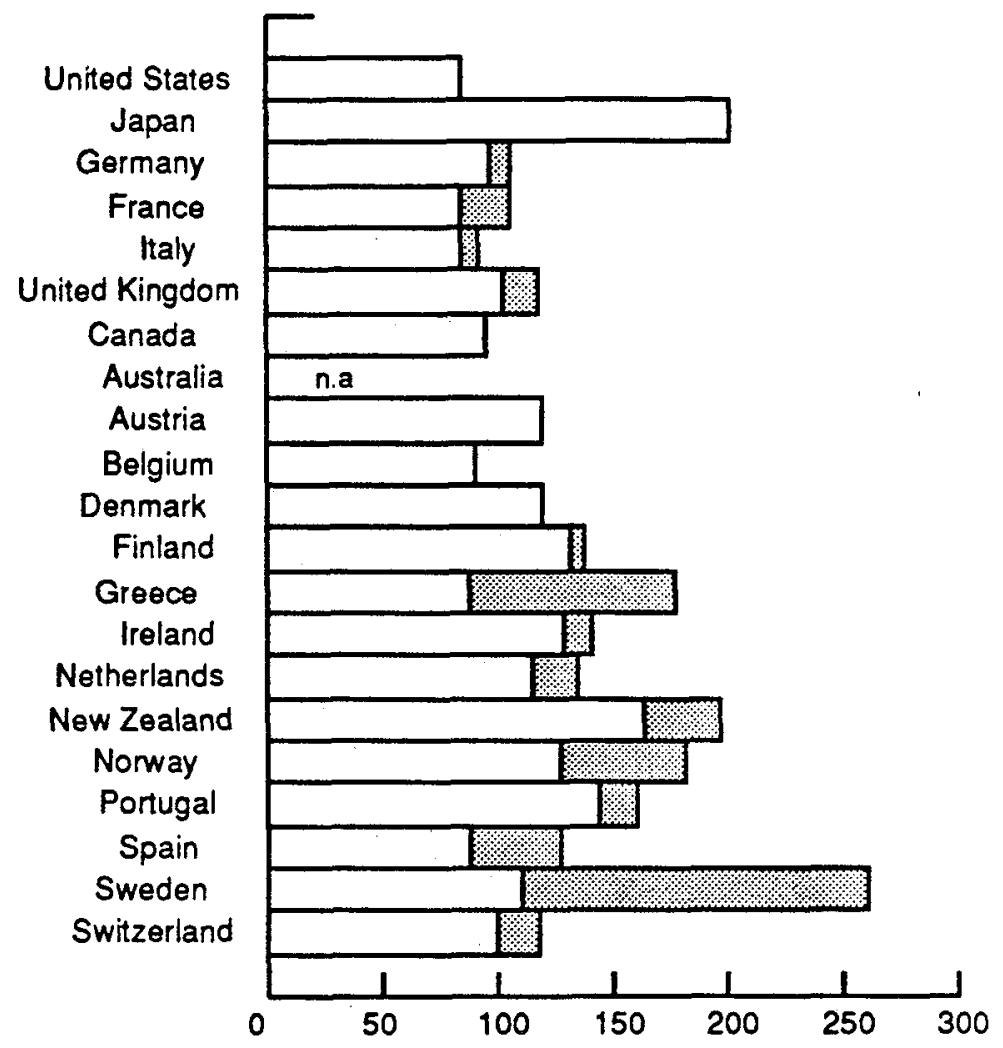

Heavy fuel oll prices in industry
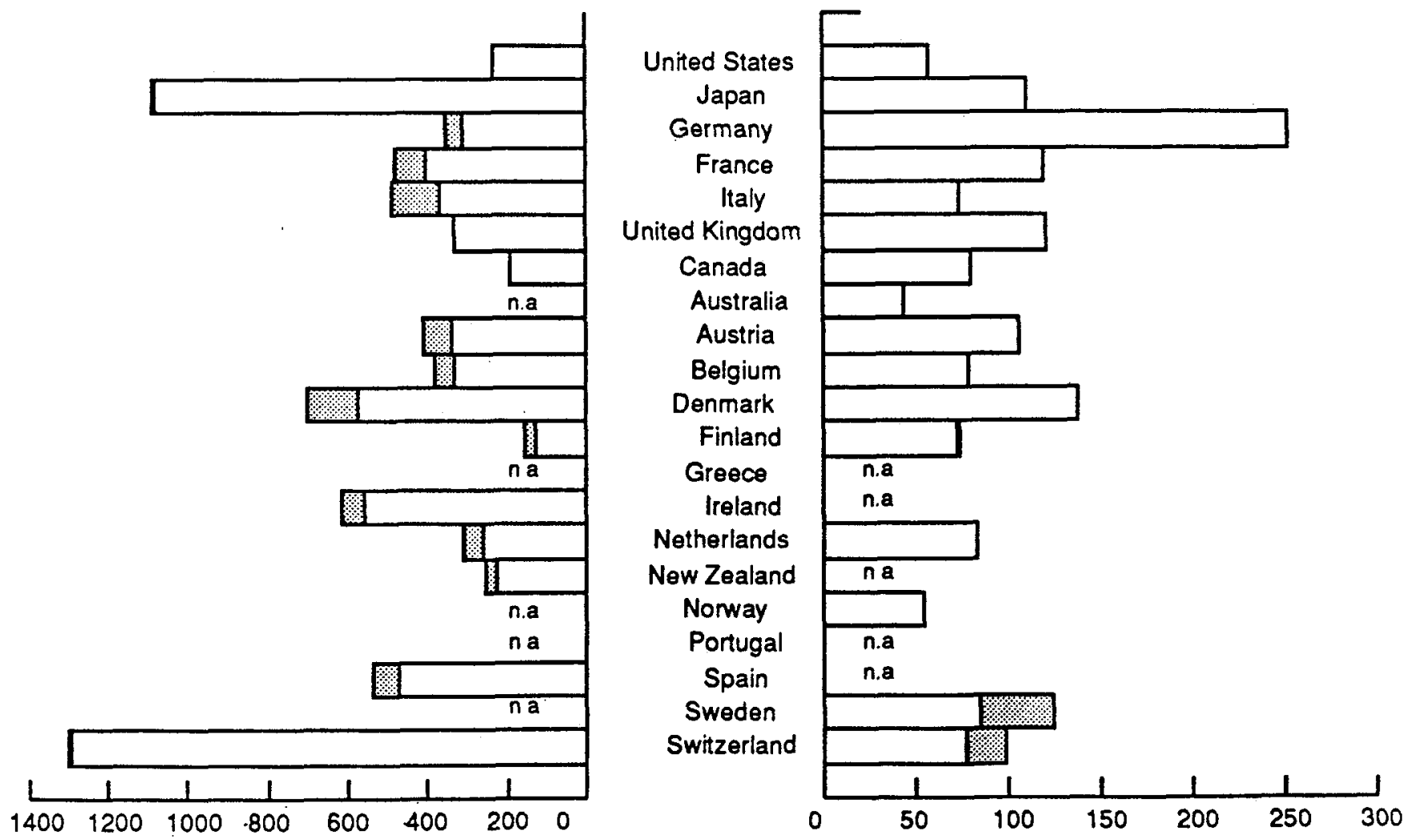

Source: IEA (1990a). 
Chart 4

\section{Carbon tax and tax revenue}

(simulation results by the GREEN model)

\section{Carbon tax}

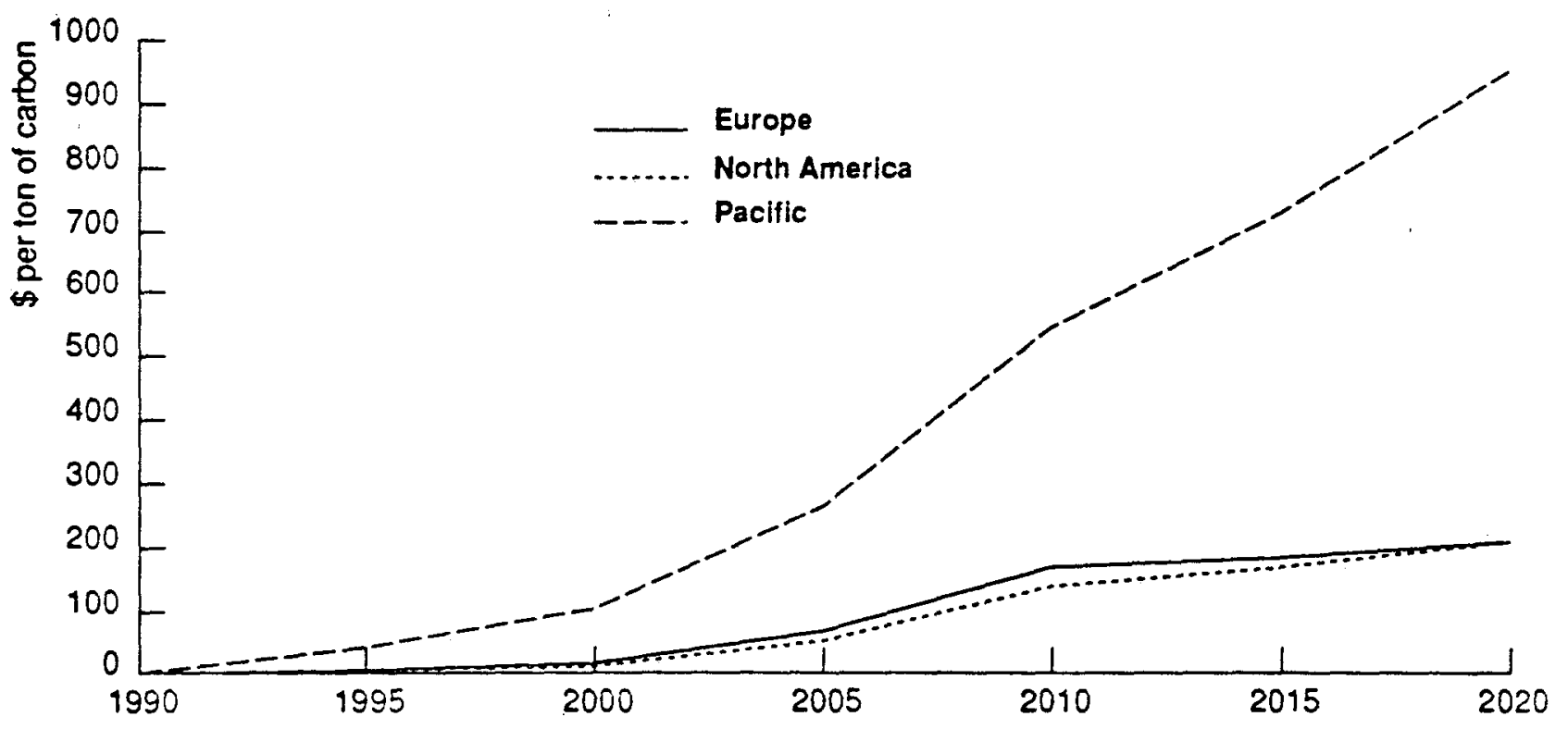

Tax revenue as per cent of GDP

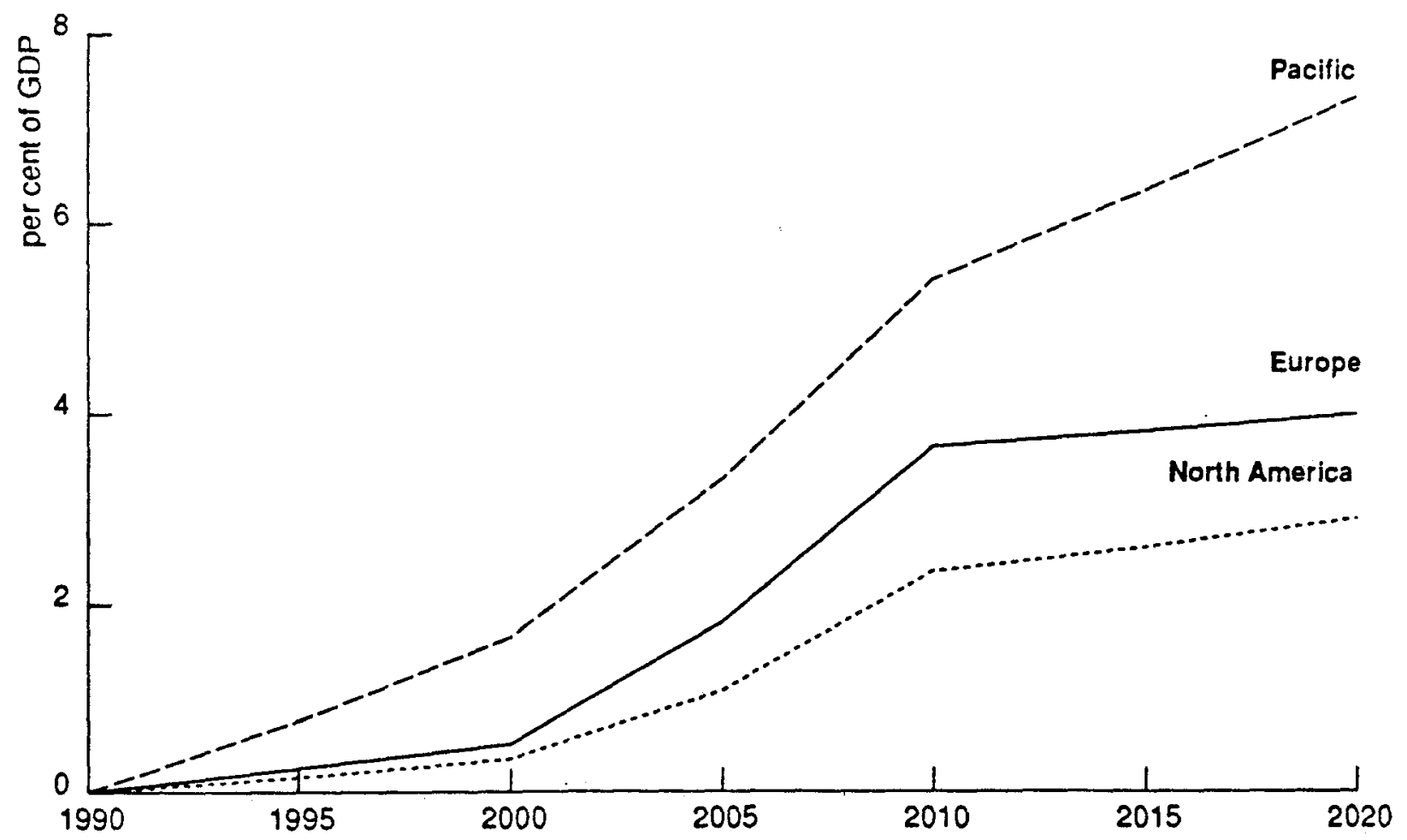

Source: Burniaux et al. (1991). 


\section{ECONOMIC AND STATISTICS DEPARTMENT}

\section{WORKING PAPERS}

A complete list of Working Papers is available on request.

105. Savings Trends and Measurement Issues

Jeffrey Shafer, Jorgen Eleskov and Warren Teast, Policy Studies Branch

104. GREEN - A Multi-Region Dynamic General Equilibrium Model for Quantifying the Costs of Curbing CO2 Emissions: A Technical Manual

J.M. Burniaux, J.P. Martin, G. Nicoletti, J. Oliveira-Martins

103. The Costs of Policies to Reduce Global Emissions of $\mathrm{CO}_{2}$ : Initial Simulation Results with GREEN

J.M. Burniaux, J.P. Martin, G. Nicoletti, J. Oliveira-Martins

102. Patterns of Recoveries for the Major Seven OECD Countries

Marco Mira d'Ercole

101. P-Star as an Indicator of Inflationary Pressure

Peter Hoeller and Pierre Poret

100. 01d Age Income Maintenance

Murray Petrie, Peter Sturm

99. The Measurement of Output and Factors of Production for the Business Sector in the 24 OECD Member Countries (March 91)

Mark Keese, Gerard Salou, Pete Richardson

98. Macroeconomic Consequences of Financial Liberalisation: A Summary Report (February 1991)

Adrian Blundell-Wignall and Frank Browne

97. Deregulation, Credit Rationing, Financial Fragility and Economic Performance (February 1991)

Michael Driscoll

96. Increasing Financial Market Integration, Real Exchange Rates and Macroeconomic Adjustment (February 1991)

Adrian Blundell-Wignall and Frank Browne

95. Financial Liberalisation, Asset Prices and Exchange Rates (February 1991) Marcus Miller and Paul Weller

94. Financial Liberalisation and International Irends in Stock, Corporate Bond and Foreign Exchange Market Volatilities (Eebruary, 1991)

Paul Kupiec

93. A macroeconomic model for Debt Analysis of the Latin America region and Debt Accounting models for the highly indebted countries

(February, 1991)

Peter Dittus and Paul O'Brien 
92. Unemployment Persistence and Insider-Outsider Forces in Wage Determination (February, 1991)

Bertil Holmlund

91. Infrastructure and Private-Sector Productivity (January 1991)

Robert Ford and Pierre Poret

90. The Public Sector: Issues for the 1990s(December, 1990)

Howard Oxley, Maria Maher, John P. Martin, Giuseppe Nicoletti and Patricia Alonso-Gamo

89. A Survey of Studies of the Costs of Reducing

Greenhouse Gas Emissions (December 1990)

Peter Hoeller, Andrew Dean and Jon Nicolaison

88. Business investment in the OECD economies: recent performance and some implications for policy (November 1990)

Robert Ford, Pierre Poret

87. The "PUZZLE" of wage moderation in the 1980s (November 1990)

Pierre Poret

86. Modelling wages and prices for the smaller OECD countries (October 1990)

Kenichi Kawasaki, Peter Hoeller, Pierre Poret

85. Simulating the OECD INTERLINK Model under Alternative Monetary Policy Rules (October 1990)

Pete Richardson

84. WALRAS - A multi-sector, multi-country applied general equilibrium model for quantifying the economy-wide effects of agricultural policies : a technical manual (August 1990)

Jean-Marc Burniaux, François Delorme, Ian Lienert and John P. Martin

83. Exchange Rate Policy in Advanced Commodity-Exporting Countries:

The Case of Australia and New Zealand

Adrian Blundell-Wignall

Robert G. Gregory

82. Economies and the environment: a survey of issues and policy options (July 1990)

Jon Nicolaisen and Peter Hoeller

81. Financial liberalisation and consumption smoothing (forthcoming)

Adrian Blundell-Wignall, Frank Browne and Stefano Cavaglia

80. Fiscal indicators (April 1990)

Edward E. Gramlich, The University of Michigan

79. Suggestions for a new set of fiscal indicators (April 1990)

Olivier Blanchard (MIT and NBER)

78. Indicators of fiscal policy: a re-examination (April 1990)

Jean-Claude Chouraqui, Robert P. Hagemann and Nicola Sartor 